\title{
スケトウダラ冷凍すり身から調製した生分解性フィルムの性状に及ぼす $\mathrm{NaCl}$ 抢よび各種有機酸塩添加の影響
}

\author{
鈴木 遼, 1 牧広 樹, ${ }^{1}$ AKASITH PORNPHATDETAUDOM, ${ }^{1}$ \\ 古川麻 美, ${ }^{2}$ 岡㠃惠美子, 1 大 迫一史 ${ }^{1 *}$ \\ (2012 年 12 月 27 日受付, 2013 年 4 月 7 日受理) \\ 1東京海洋大学, 2味の素冷凍食品株式会社
}

Effect of $\mathrm{NaCl}$ and organic salts on the properties of surimi-based films prepared from Alaska pollack frozen surimi

\section{RYO SUZUKI, ${ }^{1}$ HIROKI MAKI, ${ }^{1}$ AKASITH PORNPHATDETAUDOM, ${ }^{1}$ MAMI FURUKAWA, ${ }^{2}$ EMIKO OKAZAKI ${ }^{1}$ AND KAZUFUMI OSAKO ${ }^{*}$}

\begin{abstract}
${ }^{1}$ Department of Food Science and Technology, Tokyo University of Marine Science and Technology, Minato, Tokyo 108-8477, ${ }^{2}$ Research Institute, AJINOMOTO Corporation, Oizumimati 370-0523, Japan
\end{abstract}

The effect of $\mathrm{NaCl}$ and organic salts (Na-citrate, Na-acetate, Na-benzoate and Na-tartrate) on the properties of surimi-based films prepared from Alaska pollack frozen surimi was investigated. The solubility of the surimi protein increased upon addition of the salts. Na-citrate and $\mathrm{NaCl}$ appeared to have the highest ability to dissolve the protein among the salts. The surimi were dissolved into salt solutions at neutral $\mathrm{pH}$ and dried $\left(25 \pm 0.5^{\circ} \mathrm{C}\right.$ and $50 \pm 2 \% \mathrm{RH})$ to form the film. Physical properties and SDS-PAGE of the resultant films were determined. The films with $\mathrm{Na}$-tartrate and $\mathrm{NaCl}$ were crystallized during the drying process. By adding the salts, tensile strength (TS), elongation at break (EAB), and water vapor permeability (WVP) of the film were increased while transparency of the film was decreased (became transparent) compared to those of the control (no salts added). SDSPAGE indicated that the protein patterns of the film were not significantly different among the salt types used as a solubilizer. Na-citrate showed the highest effects on increasing TS and decreasing transparency of the film among the salts used in the study.

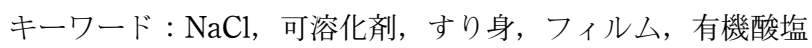

現在, 食品の包装材料として安価で軽く丈夫であるこ とから合成高分子（プラスチック）が広く用いられてい る。しかし，プラスチックの中にはこれの焼却時にダイ オキシン等の有害物質が発生するものがあること, ま た，自然界で分解されにくいものがほとんどであるた め，使用後のこれの処分が環境負荷の要因の一つとなっ ている。この問題を解決する方法の一つとして, 生分解 性の原料を用いた包装材の開発が挙げられる。生分解性 原料を用いて調製された包装材料は，プラスチックとは 異なり生分解性であることから使用後の処分が容易であ り, プラスチックフィルムと比較して環境に与える負荷 は小さいと考えられる。

現在までに, デンプン, アルギン酸, キトサン, アミ
ロース抢よびカラゲーナン等の糖類やコラーゲン, 大豆 タンパク質, 魚肉タンパク質, 小麦グルテンおよびトウ モロコシタンパク質等のタンパク質を原料とした生分解 性フィルムの開発が行われている。3)

既往の研究として, 翁らによるスケトウダラ冷凍すり 身を原料とした生分解性フィルムに関する研究があり, $\mathrm{pH}$ を酸性あるいはアルカリ性にすることにより原料中 のタンパク質を可溶化させて懸濁液（フィルム形成懸濁 液）を調製し，これを一定の条件下で乾燥することによ りフィルムの調製を行っている。文また， Leerahawong らはイカ肉を原料とした生分解性フィルムに関する研究 を行って抢り，その際に有機酸塩を用いてタンパク質を 可溶化させることによってフィルムの調製を行ってい

* Tel : 81-3-5463-0620. Fax : 81-3-5463-0620. E-mail : osako@kaiyodai.ac.jp 
る。 ${ }^{5)}$ また，タンパク質可溶化剂として用いる塩の違い により, 得られたフィルムの性状も異なることが報告さ れている。

そこで, 本研究では Leerahawong らの方法5)を参考 にして, フィルム形成懸濁液に有機酸塩を添加し, タン パク質を可溶化させる方法に関して検討を行った。ま た, 用いる有機酸塩の違いが, 得られるフィルムの性状 に及ぼす影響について検討した。

\section{試料および方法}

試料 スケトウダラ冷凍すり身（FA 級, AmericanSeafoods 社製，原材料にソルビトールおよびスクロー スを含む）を用いた。また，タンパク質可溶化剤とし て, クエン酸三ナトリウム二水和物, 酢酸ナトリウム, 酒石酸ナトリウム二水和物（いずれも特級, 和光純薬工 業株式会社製), 安息香酸ナトリウム (特級, 国産化学 株式会社製）打よび塩化ナトリウム（特級, 国産化学株 式会社製）を，フィルムの可塑剂としてグリセロール (特級, 国産化学株式会社製) を用いた。タンパク質溶 解度の測定に過塩素酸（特級, キシダ化学社製, PCA) を用いた。

一般成分の分析 冷凍すり身の一般成分は以下の方法 で測定した。すなわち, 水分含量は常圧加熱乾燥法で, 粗灰分含量は試料を $600^{\circ} \mathrm{C}$ で灰化後, それぞれ恒量に して測定した。粗タンパク質含量は Kjeldahl 法6)を用い て求めた全窒素量に 6.25 を乗じて算出し, 粗脂肪含量 は Folch 5 7)の方法で測定した。粗炭水化物含量は, 全 量 $100 （ \%)$ から水分含量, 粗タンパク質含量, 粗灰分 含量および粗脂肪含量を差し引くことにより算出した。

フィルム形成懸濁液の調製 フィルム形成懸濁液は Leerahawong らの方法5)をもとに，以下のように行っ た。すなわち, タンパク質濃度 $2 \%(\mathrm{w} / \mathrm{w})$, グリセロー ル濃度 $0.6 \%(\mathrm{w} / \mathrm{w}), \mathrm{NaCl}$, 各種有機酸塩の濃度が $0 \%$ (対照)， $0.5 \%$ 抢よび $1.0 \%(\mathrm{w} / \mathrm{w})$ となるように調製 した。全量を $100 \mathrm{~g}$ に調製後, $1 \mathrm{~N} \mathrm{NaOH}$ または $1 \mathrm{~N}$ $\mathrm{HCl}$ を用いて $\mathrm{pH}$ を 7.0 に調整した。マグネティックス ターラー $(240 \mathrm{rpm})$ で 30 分冷却・攪拌後, ガラスホ モジナイザー（スリーワンモータ HEIDON 600G 型, 新東科学株式会社製）を用いて 5 分間覺汼し，八イブ リッドミキサー（HM-500 型, キーエンス社製）を用い て脱泡を行い, フィルム形成懸濁液とした。なお, 脱泡 までの操作は全て $4^{\circ} \mathrm{C}$ 以下で行った。

フィルム形成懸濁液中のタンパク質溶解度の測定 塩 化ナトリウム $(\mathrm{NaCl})$ あるいは各種有機酸塩を用いた 際の, すり身タンパク質の塩可溶性については竹下らの 方法8) に準じて検討した。すなわち，上記の方法と同様 に調製したフィルム形成懸濁液に終濃度が $5 \%$ となる ように PCA を添加後，スパーテルを用いて混合し，30
分放置した。これをスパーテルで覺拌し, 遠心分離 (4 ${ }^{\circ} \mathrm{C}, 10000 \times g, 20$ 分）を行った。これの上清をデキャン ティングにより取り除き, 沈殿物に対して $5 \% \mathrm{PCA} を$ 用いて同様の操作を 3 回行った。得られた沈殿物は風 乾後, $1 \mathrm{~N} \mathrm{NaOH}$ を加えて一晚振とうして溶解後, Lowry 法9)でタンパク質濃度を測定し, フィルム形成懸濁液 中の全タンパク質量とした $(\mathrm{A})$ 。また, フィルム形成 懸濁液を遠心分離 $\left(4^{\circ} \mathrm{C}, 20000 \times g, 30\right.$ 分）して得られ た上清に終濃度が $5 \%$ となるようにPCA を添加し, 得 られた沈殿物を同様に風乾したのち,これのタンパク質 濃度を測定してこれを溶解したタンパク質量とした (B)。フィルム形成懸濁液の全タンパク質量に対する遠 心分離後の上清の溶解したタンパク質量をタンパク質溶 解度とし, 以下の式で算出した。

溶解度 $(\%)=(B / A) \times 100$

$A=$ フィルム形成懸濁液のタンパク質濃度 $(\mathrm{mg} / \mathrm{mL})$ $B=$ 遠心分離後の上清のタンパク質濃度 $(\mathrm{mg} / \mathrm{mL})$

フィルムの調製 上記の方法と同様に調製したフィル ム形成懸濁液 $4 \mathrm{~g}$ をシリコン樹脂製の枠 $(5 \mathrm{~cm} \times 5 \mathrm{~cm})$ 内に流し込反, 恒温恒湿機 (KCL-2000A 型, 東京理化 器械株式会社製）を用いて, $25 \pm 0.5^{\circ} \mathrm{C}$, 相対湿度 $50 \pm$ $2 \%$ で 48 時間乾燥させてフィルムを調製した。フィル ムをシリコン樹脂から丁寧に剥がし, $25 \pm 0.5^{\circ} \mathrm{C}$, 相対 湿度 $50 \pm 2 \%$ の恒温恒湿機内で, さらに 24 時間コンデ ィショニングを行い,これの諸性状を検討した。

フィルムの機械的性質の測定 フィルムを幅 $20 \mathrm{~mm}$, 長さ $45 \mathrm{~mm}$ に切断し, フィルムの厚さをシックネス ゲージ（No. 2046F Shock Proof，株式会社ミットヨ製） により 6 点測定後, ASTM 標準法であるASTM. D. 882-9710) に従って, テンシプレッサー（TTP-50BX II 型, 有限会社タケトモ電機製）を用いて引っ張り試験を 行った。両端のグリップの間隔およびクロスヘッドス ピードはそれぞれ $30 \mathrm{~mm}$ 打よび $0.5 \mathrm{~mm} / \mathrm{s}$ とした。引 っ張り強度 (Tensile strength, TS) 抒よび引っ張り伸 び率 (Elongation at break, EAB) は以下の式から算出 した。

$\mathrm{TS}(\mathrm{MPa})=F / S$

$F=$ 引っ張り強度 $(\mathrm{N}), S=$ フィルムの断面積 $\left(\mathrm{m}^{2}\right)$

$\operatorname{EAB}(\%)=(E / 30) \times 100$

$E=$ フィルムの伸び $(\mathrm{mm})$

フィルムの水蒸気透過性 (Water vapor permeability, WVP) の測定 フィルムを $5 \mathrm{~cm} \times 5 \mathrm{~cm}$ に切断し, フィルムの厚さをシックネスゲージにより 6 点測定 後, 実験に供した。WVPは, ASTM 法を用いた Gontard らの方法11)に準じて測定を行った。すなわち, 内 径 $2.6 \mathrm{~mm}$, 高さ $7.8 \mathrm{~mm}$ のガラス製バイアル瓶に完全 に乾燥させたシリカゲルを充填した後, フィルムで瓶口 を覆った。この際, フィルムと瓶口の間に隙間がないよ 
うに，瓶口に真空グリスを塗布し，プラスチックリング で固定した。次に，蒸留水により飽和状態（RH100\%） に調整したデシケーター内にバイアル瓶を置き，デシ ケーターを $30^{\circ} \mathrm{C}$ の恒温器中に放置し, 8 時間経過まで 1 時間毎にバイアル瓶の重量を測定した。WVP ( $・$ $\left.\mathrm{m}^{-1} \cdot \mathrm{s}^{-1} \cdot \mathrm{Pa}^{-1}\right)$ は以下の式により算出した。

$$
\begin{aligned}
\mathrm{WVP} & \left(\mathrm{g} \cdot \mathrm{m}^{-1} \cdot \mathrm{s}^{-1} \cdot \mathrm{Pa}^{-1}\right) \\
& =w \cdot x \cdot A^{-1} \cdot t^{-1} \cdot\left(P_{2}-P_{1}\right)
\end{aligned}
$$

$w=$ 重量変化量 $(\mathrm{g}), x=$ フィルム厚さ $(\mathrm{m}), t=$ 時間 $(\mathrm{s}), A=$ バイアル瓶の口の面積 $\left(\mathrm{m}^{2}\right),\left(P_{2}-P_{1}\right)=$ デシ ケーター内とバイアル瓶内の圧力差 $(\mathrm{Pa})$

フィルムの光透過性および吸光度の測定 フィルムの 厚さをシックネスゲージにより 6 点測定後, ASTM 法 D.1746-92 (ASTM.1987) ${ }^{12}$ に従って紫外可視分光光度 計（UV-160 型，島津製作所株式会社製）を用いて 200 $\mathrm{nm}$ から $800 \mathrm{~nm}$ までの光透過度を測定し, 吸光度は以 下の式で算出した。

吸光度 $=(-\log T) / a$

$T=600 \mathrm{~nm}$ における光透過度, $a=$ フィルムの厚さ $(\mathrm{mm})$

フィルムの色調および白色度の測定 フィルムの色調 は, カラーリーダー (CR-13 型, コニカミノルタセン シング株式会社製）を用いて 1 枚につき 3 点測定し， $L^{*}, a^{*}, b^{*}$ で表した。その際, フィルムの下に, 本研究 で使用したカラーリーダーの色調校正版を敷き測定を行 った。また, 白色度は以下の式から算出した。

白色度 $=100-\left[\left(100-L^{*}\right)^{2}+a^{* 2}+b^{* 2}\right]^{1 / 2}$

ポリアクリルアミド電気泳動（SDS-PAGE）すり身 フィルムに液体窒素を加えて乳棒を用いてすり潰し, 粉 末状にした。得られた粉末 $80 \mathrm{mg}$ に $2 \%$ メルカプトエ タノール $-2 \% \mathrm{SDS}-8 \mathrm{M}$ 尿素 $-20 \mathrm{mM}$ Tris- $\mathrm{HCl}$ 溶液 $(\mathrm{pH} 8.8)$ を $10 \mathrm{~mL}$ 加え, $100^{\circ} \mathrm{C}$ で 2 分加熱後, 水冷し, 一晚振とうした。 $2 \% \mathrm{SDS}-8 \mathrm{M}$ 尿素 $-20 \mathrm{mM}$ Tris- $\mathrm{HCl}$ 溶液（pH 8.8）により透析を行い, 遠心分離 $\left(25^{\circ} \mathrm{C}\right.$, $10000 \times g, 20$ 分）後, 上清のタンパク質濃度をLowry 法により測定し SDS-PAGE サンプルを調製した。

SDS-PAGE は Laemmli の方法13)に従い, 市販のアク リルアミドゲル（7.5\%，パジェル NPU-7.5L，アトー 社製）を用いて行った。分子量マーカーとして, Page Ruler ${ }^{\mathrm{TM}}$ Unstained Protein Ladder (Fermentas Life Sciences 社製）を用い，染色は 0.025\% Coomassie Brilliant Blue R-250-5\% メタノール - 10\% 眽酸溶液で行 い, 脱色は $30 \%$ メタノール $-10 \%$ 酢酸溶液を用いて行 った。
結果

試料の一般成分 試料として用いたスケトウダラ冷凍 すり身の一般成分を Table 1 に示した。試料の一般成分 は水分含量 $76 \%$, 粗タンパク質含量 $15.8 \%$, 灰分含量 $0.58 \%$, 粗脂肪含量 $0.11 \%$ 押よび粗炭水化物含量 $7.5 \%$ であった。

タンパク質溶解度 タンパク質溶解度を Table 2 に示 した。本研究では, 有機酸塩の濃度として $0.5 \%$ 抢よび $1.0 \%$ のみ用いたが，これは $1.0 \%$ 以上の濃度の有機 酸塩を添加してフィルムにした際に, 有機酸塩の種類に 関わらずこれの析出が見られ，均質なフィルムが得られ なかったためである。Table 2 に示すように, $\mathrm{NaCl}$ あ るいは各種有機酸塩を添加した場合, タンパク質溶解度 は対照と比較して上昇した。フィルム形成懸濁液に 0.5 $\%$ の $\mathrm{NaCl}$ あるいは各種有機酸塩を添加した場合, クエ ン酸 $\mathrm{Na}$ 抢よび $\mathrm{NaCl}$ に抢いて特に高い值 (12.2-12.7\%) を示し, 酢酸 $\mathrm{Na}$ 抢よび安息香酸 $\mathrm{Na}$ において低い值 (8.5-8.9\%) を示した。有機酸塩類の添加量を $1.0 \%$ に した場合, 有機酸塩類を $0.5 \%$ 添加した場合と比較して タンパク質溶解度は上昇し, クエン酸 $\mathrm{Na}$ および酒石酸 $\mathrm{Na}$ に抢いて特に高い值（14.2-14.8\%）を示した。

Table 1 Proximate components of Alaska pollack frozen surimi*

\begin{tabular}{lcccc}
\hline \multicolumn{5}{c}{ Proximate components $(\%)$} \\
\hline \multirow{2}{*}{ Moisture } & Crude & Crude & Crude & Crude \\
& protein & ash & lipids & carbohydrate \\
$76.0 \pm 0.1$ & $15.8 \pm 0.19$ & $0.59 \pm 0.06$ & $0.11 \pm 0.02$ & 7.5 \\
\hline
\end{tabular}

* Data are shown as mean \pm S.D. $(n=3)$.

Table 2 The effect of organic salts on the solubility of surimi protein ${ }^{1,2}$

\begin{tabular}{lcc}
\hline Salts & Conc. $(\%)$ & Solubility of surimi protein $(\%)$ \\
\hline Control & - & $7.3 \pm 0.9^{\mathrm{f}}$ \\
Na-citrate & 0.5 & $12.7 \pm 1.1^{\mathrm{c}}$ \\
& 1 & $14.2 \pm 0.3^{\mathrm{ab}}$ \\
Na-acetate & 0.5 & $8.5 \pm 0.3^{\mathrm{e}}$ \\
& 1 & $9.7 \pm 0.6^{\mathrm{d}}$ \\
Na-benzoate & 0.5 & $8.9 \pm 0.3^{\mathrm{de}}$ \\
& 1 & $11.9 \pm 0.8^{\mathrm{c}}$ \\
Na-tartrate & 0.5 & $9.5 \pm 0.4^{\mathrm{d}}$ \\
& 1 & $14.8 \pm 0.6^{\mathrm{a}}$ \\
$\mathrm{NaCl}$ & 0.5 & $12.2 \pm 0.1^{\mathrm{c}}$ \\
& 1 & $13.7 \pm 0.6^{\mathrm{b}}$
\end{tabular}

\footnotetext{
${ }^{1}$ Data are shown as mean \pm S.D.

${ }^{2}$ Different letters indicate significant differences $(p<0.05, n=3)$.

Protein solubility $(\%)=(B / A) \times 100$. " $A$ " and " $B$ " mean protein concentration before centrifugation $(\mathrm{mg} / \mathrm{mL})$ and protein concentration of supernatant after centrifugation, respectively $(\mathrm{mg} / \mathrm{mL})$.
} 
フィルムの機械的性質およびSDS-PAGE $\mathrm{NaCl}$ お よび各種有機酸塩をフィルム形成懸濁液に $0.5 \%$ 抢よび $1.0 \%$ 添加して調製したフィルムの写真をそれぞれ Fig. 1a 抢よび Fig. 1bに示した。塩化ナトリウム抢よび用 いた有機酸塩の種類にかかわらずフィルムは得られた。 酒石酸 $\mathrm{Na}$ 抢よび $\mathrm{NaCl}$ を添加して調製したフィルムで は塩の析出が見られたが，それ以外のものは市販のオブ ラートに近い，ほぼ均質なものであった。

またフフィルムの厚さを Table 3 に示した。調製した フィルムの厚さは, 安息香酸 $\mathrm{Na} 1.0 \%$ 添加したフィ ルムにおいて高い值 $(42.9 \mu \mathrm{m})$ を示し， $\mathrm{NaCl}$ を $1.0 \%$ 添加したフィルムにおいて低い值 $(32.9 \mu \mathrm{m})$ を示した。 有機酸塩の添加量を $0.5 \%$ から $1.0 \%$ にした場合, 酢酸 $\mathrm{Na}$ では有意差は見られず，クエン酸 $\mathrm{Na}$ 抢よび安息香 酸 $\mathrm{Na}$ に抢いて増加する傾向を示し, 酒石酸 $\mathrm{Na}$ 打よび

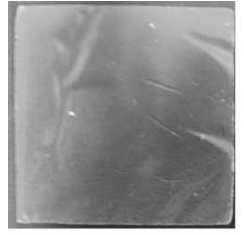

Control

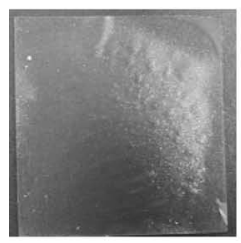

Na-benzoate

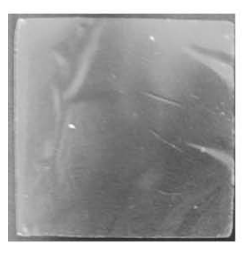

Control

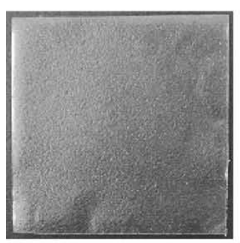

Na-benzoate

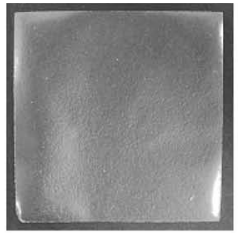

Na-citrate

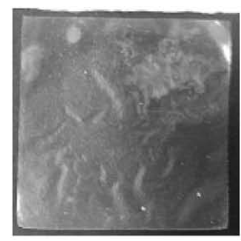

Na-tartrate

(a)

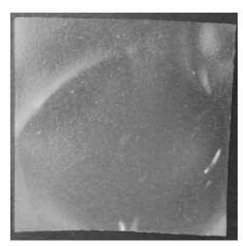

Na-citrate

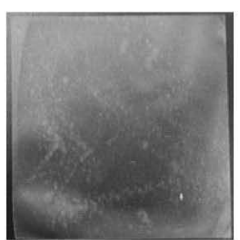

Na-tartrate

(b)

Fig. 1 Surimi-based films prepared by addition of organic salts with different salt types: (a) salt concentration is $0.5 \%$ in film forming solution; (b) salt concentration is $1.0 \%$.
$\mathrm{NaCl}$ において減少する傾向を示した。

フィルムの TS を Fig. 2 に示した。 $\mathrm{NaCl}$ あるいは各 種有機酸塩を添加することにより, 対照と比較して高い 值を示した。フィルム形成懸濁液に $0.5 \%$ の $\mathrm{NaCl}$ ある いは有機酸塩を添加したものでは, フィルムの TS はク エン酸 $\mathrm{Na}$, 酒石酸 $\mathrm{Na}$ 抢よび $\mathrm{NaCl}$ に打いて高い值 （4.6-5.1 MPa）を示し, 酰酸 $\mathrm{Na}$ 抢よび安息香酸 $\mathrm{Na}$ 添加して調製したフィルムはこれらに比較して有意に低 い值（3.3-3.6 MPa）を示した。有機酸塩の添加量を $1.0 \%$ にした場合は, 酶酸 Na を除いてTSは減少し, 安息香酸 $\mathrm{Na}$ を添加したものは特に低い值 $(2.3 \mathrm{MPa})$ を示した。 $\mathrm{NaCl}$ では添加濃度の違いによる有意差は見 られなかった。

各種塩類を $0.5 \%$ 抢よび $1.0 \%$ 添加した際の SDSPAGEの結果をそれぞれ Fig. 3a 抢よび Fig. 3bに示し た。 $\mathrm{NaCl}$ 打よび各種有機酸塩の添加は, フィルムタン パク質の分子量分布に影響を及ぼさなかった。また, 各 種塩類の添加量の違いによる影響も見られなかった。一 方, スルメイカの外套膜筋肉から調製したフィルムに打 いては, 可溶化剤として用いる塩の違いがフィルムの TS に影響を及ぼし， $\mathrm{NaCl}$ 抢よび酢酸 $\mathrm{Na}$ を添加したも のは低く, クエン酸 Naを添加したものは高いことが報 告されている。さらに, フィルムのタンパク質中のミオ シンヘビーチェーンの残存量と物性との間にも高い相関 が見られている。 ${ }^{5)}$ Fig. 4 に示すように, $\mathrm{EAB}$ は $\mathrm{NaCl}$ および各種有機酸塩類の添加により対照と比較して高い 值（139-201\%）を示した。フィルム形成懸濁液に 0.5 $\%$ の $\mathrm{NaCl}$ あるいは各種有機酸塩を添加したものでは, $\mathrm{EAB}$ の值は安息香酸 $\mathrm{Na}$ 抢よび $\mathrm{NaCl}$ に打いて高い值 (172-175\%) を示した。また，有機酸塩類の添加量を $1.0 \%$ にした場合, 安息香酸 Naにおいて特に高い值

Table 3 Effect of organic salts on the thickness of surimibased films

\begin{tabular}{lll}
\hline Salts & $\begin{array}{c}\text { Conc. } \\
(\% \mathrm{w} / \mathrm{w})\end{array}$ & Thickness $(\mu \mathrm{m})$ \\
\hline Control & - & $40.5 \pm 3.3^{\mathrm{bc}}$ \\
$\mathrm{Na}-$ citrate & 0.5 & $38.1 \pm 1.8^{\mathrm{de}}$ \\
$\mathrm{Na}-$ acetate & 0.5 & $37.4 \pm 2.0^{\mathrm{e}}$ \\
$\mathrm{Na}$-benzoate & 0.5 & $39.7 \pm 1.8^{\mathrm{cd}}$ \\
$\mathrm{Na}$-tartrate & 0.5 & $40.0 \pm 2.2^{\mathrm{bcd}}$ \\
$\mathrm{NaCl}$ & 0.5 & $34.3 \pm 2.1^{\mathrm{fg}}$ \\
$\mathrm{Na}-$ citrate & 1 & $42.2 \pm 1.3^{\mathrm{ab}}$ \\
$\mathrm{Na}-$ acetate & 1 & $38.1 \pm 2.1^{\mathrm{de}}$ \\
$\mathrm{Na}-$ benzoate & 1 & $42.9 \pm 1.6^{\mathrm{a}}$ \\
$\mathrm{Na}-$ tartrate & 1 & $36.1 \pm 1.0^{\mathrm{ef}}$ \\
$\mathrm{NaCl}$ & 1 & $32.9 \pm 0.7^{\mathrm{g}}$ \\
\hline
\end{tabular}

*1 Data are shown as mean \pm S.D.

*2 Different letters in the same column indicate significant differences $(p<0.05, n=3)$. 


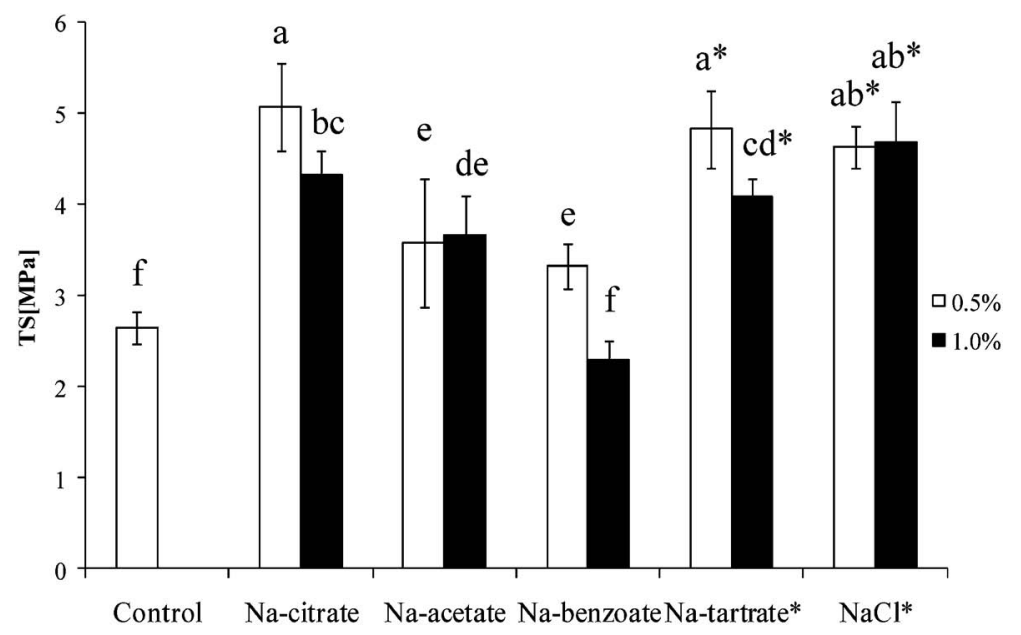

Fig. 2 Effect of salt types and their concentration on tensile strength of surimi-based films. Bars represent standard deviation $(n=$ $6)$. Different letters indicate significant differences $(p<0.05) . *$ indicates crystallization of salt on the surface of the films. Tensile strength $(\mathrm{MPa})=F / S$. " $F$ " is the maximum load $(\mathrm{N})$ necessary to pull the sample apart and " $S$ " is the cross-sectional area of the sample film $\left(\mathrm{m}^{2}\right)$.

(a)

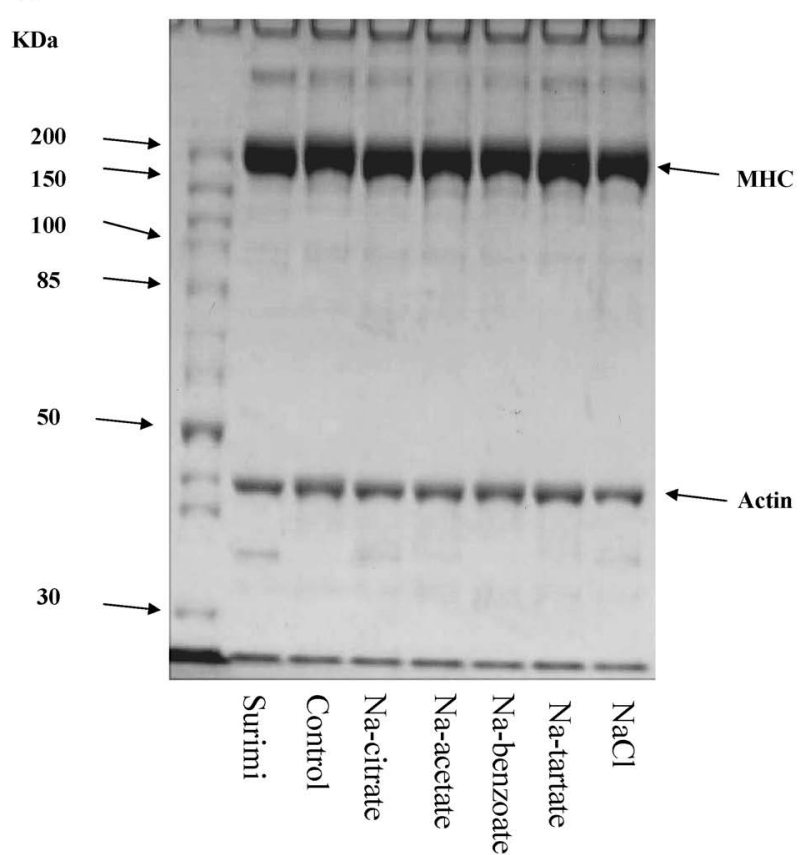

(b)

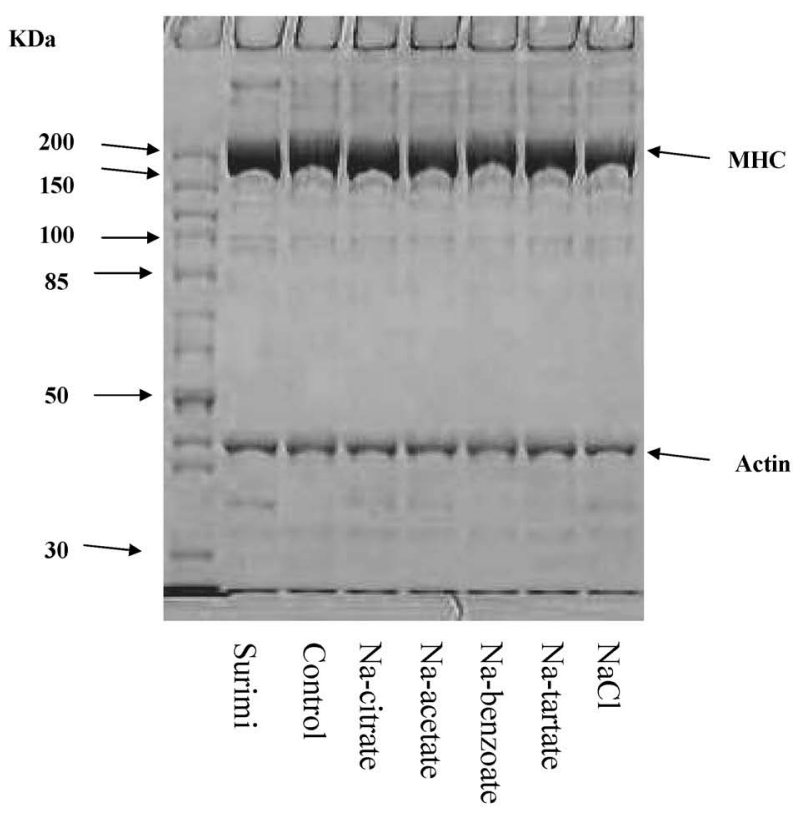

Fig. 3 SDSPAGE patterns of frozen surimi and surimi-based films with different salt types: (a) salt concentration is $0.5 \%$ in film forming solution; (b) salt concentration is $1.0 \%$. "MHC" is myosin heavy chain.

（201\%）を示し，酒石酸 Naにおいて低い值（62\%）を 示した。クエン酸 Na はフィルム形成懸濁液に $0.5 \%$ 添 加時と $1.0 \%$ 添加した際で有意差は無かったが, 酢酸 $\mathrm{Na}$ ，安息香酸 $\mathrm{Na}$ および $\mathrm{NaCl}$ では添加量の増大に伴い $\mathrm{EAB}$ は上昇し, 酒石酸 $\mathrm{Na}$ では減少した。酒石酸 $\mathrm{Na} 1.0 \%$ 添加により調製したフィルムは, 他のフィルム と比較して $\mathrm{EAB} の$ 值が著しく低く $(62 \%)$ ，また，

Fig. 1bに示したように塩の析出が見られ, 固く脆く,
明らかに他のフィルムと異なる性状であった。

水蒸気透過性（WVP）フィルムのWVPの結果を Fig. 5 に示した。 $\mathrm{NaCl}$ および各種有機酸塩を添加する ことにより, WVPの值は対照と比較して増加した $\left(0.96 \times 10^{-10}-1.5 \times 10^{-10} \mathrm{~g} \cdot \mathrm{m}^{-1} \cdot \mathrm{s}^{-1} \cdot \mathrm{Pa}^{-1}\right)$ 。各種有機 酸塩を $0.5 \%$ 添加した場合, WVPはクエン酸 $\mathrm{Na}$, 酢 酸 $\mathrm{Na}$ および $\mathrm{NaCl}$ において高い值（1.20×10-10-1.24 $\left.\times 10^{-10} \mathrm{~g} \cdot \mathrm{m}^{-1} \bullet \mathrm{s}^{-1} \cdot \mathrm{Pa}^{-1}\right)$ を示した。有機酸塩の添加 


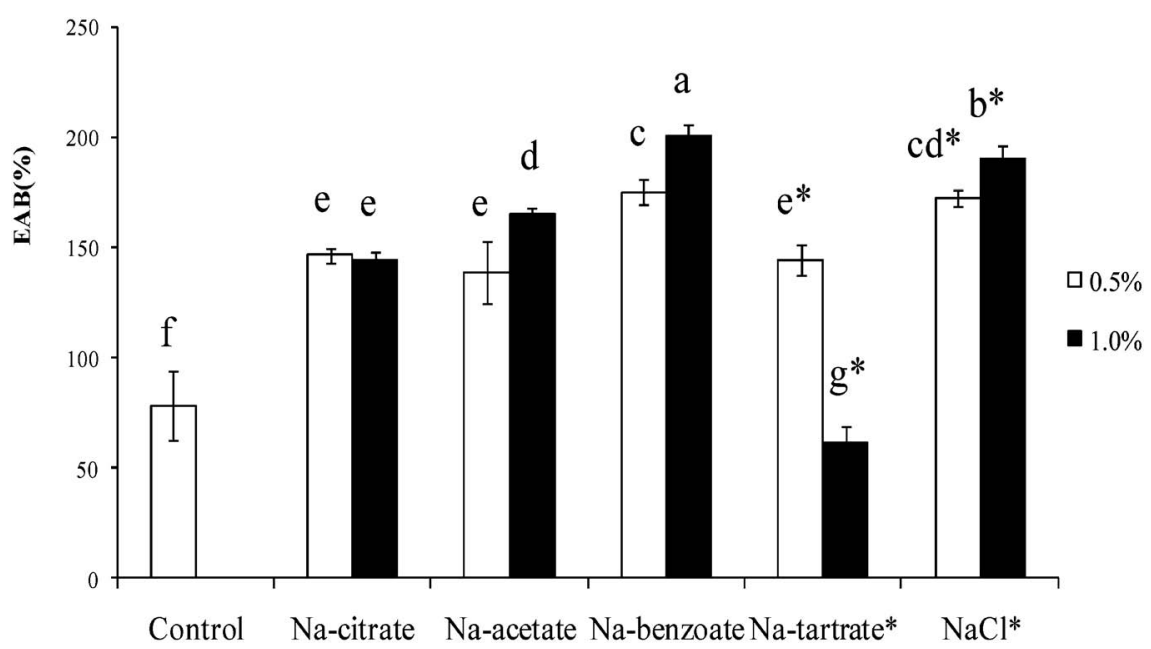

Fig. 4 Effect of salt types and their concentration on elongation at break of surimi-based films. Different letters indicate significant differences $(p<0.05, n=6)$. * indicates crystallization of salt on the surface of the films. Elongation at break $(\%)=(E / 30) \times$ 100. " $E$ " is the elongation at the moment of rupture $(\mathrm{mm})$ and the " 30 " $(\mathrm{mm})$ is the initial grip length.

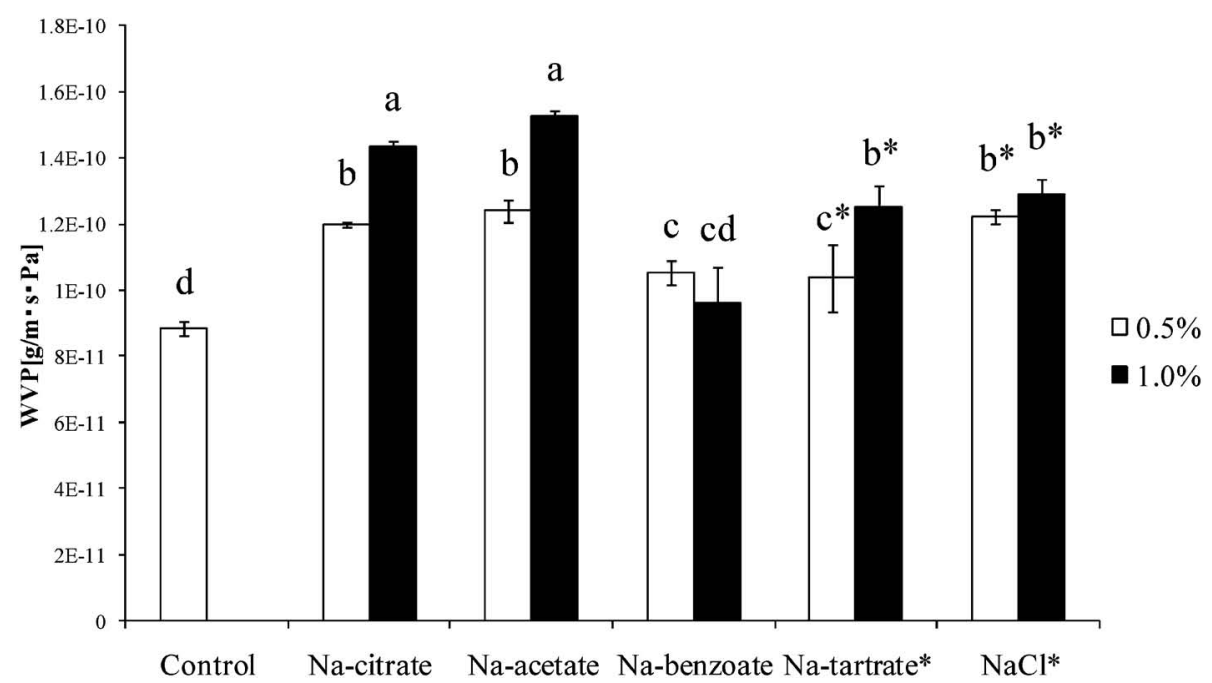

Fig. 5 Water vapor permeability of surimi films from film forming solution (FFS) with different salt types and concentrations. Bars represent standard deviation $(n=3)$. Different letters indicate significant difference $(p<0.05)$. *indicates crystallization of salt on the surface of the films. Water vapor permeability $\left(\mathrm{g} \cdot \mathrm{m}^{-1} \cdot \mathrm{s}^{-1} \cdot \mathrm{Pa}^{-1}\right)=w \cdot x \cdot A^{-1} \bullet t^{-1} \bullet\left(P_{2}-P_{1}\right)$. " $w$ " is the weight gain of the cup $(\mathrm{g})$, " $x$ " is the film thickness $(\mathrm{m})$, " $A$ " is the area of exposed film $\left(\mathrm{m}^{2}\right)$, " $t$ " is the storage time ( $)$, and " $\left(P_{2}-P_{1}\right)$ " is the vapor pressure differential across the film $(\mathrm{Pa})$.

量を $1.0 \%$ にした場合, 安息香酸 $\mathrm{Na}\left(9.6 \times 10^{-11} \mathrm{~g}\right.$ ・ $\left.\mathrm{m}^{-1} \cdot \mathrm{s}^{-1} \cdot \mathrm{Pa}^{-1}\right)$ を除き, $0.5 \%$ 添加フィルムと比較し てWVPの值は増加し $\left(1.25 \times 10^{-10}-1.5 \times 10^{-10} \mathrm{~g} ・\right.$ $\left.\mathrm{m}^{-1} \cdot \mathrm{s}^{-1} \cdot \mathrm{Pa}^{-1}\right)$, 酢酸 $\mathrm{Na}$ を添加したフィルムにおいて 最も大きな值 $\left(1.5 \times 10^{-10} \mathrm{~g} \cdot \mathrm{m}^{-1} \bullet \mathrm{s}^{-1} \cdot \mathrm{Pa}^{-1}\right)$ を示した。 $\mathrm{NaCl}$ では添加量の違いによる有意な差は見られなかっ た。

フィルムの光透過率および吸光度 フィルムの各波長 に拈ける光透過率および吸光度の結果を Table 4 に示し た。塩の添加の有無, 塩の種類および添加量に関わら ず，すり身フィルムは $200 \mathrm{~nm}$ および $280 \mathrm{~nm}$ の紫外部
の光を透過しない性質を有していた $(0.3 \%)$ 。をた, 可 視光である $600 \mathrm{~nm}$ に打ける吸光度に拈いては, $\mathrm{NaCl}$ および各種有機酸塩を $0.5 \%$ 添加した場合, 安息香酸 $\mathrm{Na}$ 添加に抢いて最も低く（2.0), $\mathrm{NaCl}$ 添加においては 最も高かった (7.2)。このことは, 安息香酸 $\mathrm{Na}$ を用い てフィルムを調製した場合, 最も透明に近いフィルムが 得られることを示している。各種塩類の添加量を $1.0 \%$ にした場合, $0.5 \%$ 添加した場合と比較して吸光度の值 は高くなる傾向を示し, $\mathrm{NaCl}$ 添加に抢いて特に高い值 (9.6) を示した。

また, 各種有機酸塩添加フィルムは, 添加量に関わら 
Table 4 Effect of salt types and concentrations on light transmission (\%) and transparency of surimi-based films ${ }^{1,2}$

\begin{tabular}{|c|c|c|c|c|c|c|c|c|c|}
\hline \multirow{2}{*}{ Salts } & \multirow{2}{*}{$\begin{array}{l}\text { Conc. } \\
(\% \mathrm{w} / \mathrm{w})\end{array}$} & \multicolumn{8}{|c|}{ Light transmission at different wavelengths (nm) } \\
\hline & & 200 & 280 & 350 & 400 & 500 & 600 & 800 & Transparency \\
\hline Control & - & 0.3 & 0.3 & $53.3 \pm 2.2$ & $63.3 \pm 1.2$ & $66.6 \pm 0.9$ & $67.9 \pm 0.9$ & $68.7 \pm 0.5$ & $5.78 \pm 0.4^{\mathrm{c}}$ \\
\hline $\mathrm{Na}$-citrate & 0.5 & 0.3 & 0.3 & $68.5 \pm 1.4$ & $75.5 \pm 0.5$ & $78.7 \pm 0.4$ & $80.1 \pm 0.4$ & $80.9 \pm 0.5$ & $2.72 \pm 0.1^{g}$ \\
\hline $\mathrm{Na}$-acetate & 0.5 & 0.3 & 0.3 & $60.7 \pm 1.2$ & $66.5 \pm 0.8$ & $70.6 \pm 1.0$ & $71.7 \pm 1.0$ & $73.0 \pm 1.0$ & $4.23 \pm 0.2^{\mathrm{d}}$ \\
\hline Na-benzoate & 0.5 & 0.3 & 0.3 & $76.7 \pm 0.4$ & $80.8 \pm 0.3$ & $84.0 \pm 0.1$ & $85.2 \pm 0.1$ & $86.1 \pm 0.1$ & $1.97 \pm 0.0^{\mathrm{h}}$ \\
\hline $\mathrm{Na}$-tartrate & 0.5 & 0.3 & 0.3 & $56.2 \pm 6.7$ & $63.7 \pm 7.5$ & $68.1 \pm 6.9$ & $69.9 \pm 6.3$ & $72.2 \pm 5.7$ & $3.64 \pm 0.7 \mathrm{e}$ \\
\hline $\mathrm{NaCl}$ & 0.5 & 0.3 & 0.3 & $44.9 \pm 3.7$ & $54.3 \pm 2.8$ & $58.6 \pm 3.2$ & $60.9 \pm 3.2$ & $63.9 \pm 4.0$ & $7.15 \pm 1.1^{\mathrm{b}}$ \\
\hline $\mathrm{Na}$-citrate & 1.0 & 0.3 & 0.3 & $57.0 \pm 2.1$ & $69.1 \pm 0.7$ & $73.4 \pm 0.6$ & $75.3 \pm 0.7$ & $77.0 \pm 0.7$ & $3.15 \pm 0.1^{\text {efg }}$ \\
\hline $\mathrm{Na}$-acetate & 1.0 & 0.3 & 0.3 & $55.7 \pm 0.8$ & $63.3 \pm 0.8$ & $69.0 \pm 0.8$ & $71.0 \pm 0.8$ & $73.4 \pm 0.7$ & $4.48 \pm 0.1^{\mathrm{d}}$ \\
\hline Na-benzoate & 1.0 & 0.3 & 0.3 & $62.5 \pm 6.6$ & $71.1 \pm 4.6$ & $76.3 \pm 3.4$ & $78.5 \pm 2.7$ & $80.4 \pm 1.6$ & $2.80 \pm 0.5^{\mathrm{f}}$ \\
\hline $\mathrm{Na}$-tartrate & 1.0 & 0.3 & 0.3 & $57.1 \pm 2.2$ & $66.2 \pm 1.8$ & $71.1 \pm 1.8$ & $73.0 \pm 1.6$ & $74.9 \pm 1.1$ & $3.29 \pm 0.2^{\mathrm{efg}}$ \\
\hline $\mathrm{NaCl}$ & 1.0 & 0.3 & 0.3 & $31.4 \pm 0.8$ & $43.4 \pm 0.4$ & $47.2 \pm 0.4$ & $48.9 \pm 0.4$ & $51.6 \pm 0.5$ & $9.61 \pm 0.1^{\mathrm{a}}$ \\
\hline
\end{tabular}

${ }^{1}$ Data are shown as mean \pm S.D.

2 Different letters in the same column indicate significant differences $(p<0.05, n=3$. $)$.

Transparency $=(-\log T) / a$. " $T$ " is light transmission at $600 \mathrm{~nm}$. " $a$ " is film thickness $(\mathrm{mm})$.

ず対照と比較して低い吸光度を示し, 対照のフィルムで はやや白濁していた。

フィルムの色調および白色度 フィルム形成懸濁液に $0.5 \%$ の $\mathrm{NaCl}$ あるいは各種有機酸塩を添加した場合, 白色度の值は酒石酸 $\mathrm{Na}$ を添加したフィルムを除いて対 照と比較して減少したが，大きな差は見られなかった (93.8-93.9)。添加量を 1.0\%にした場合, クエン酸 $\mathrm{Na}$ では白色度が増加したが, 他の塩類では $0.5 \%$ 添加の場 合と比較して有意な差は無かった。また，添加する塩の 種類によってフィルムの色調および白色度に若干の差は 見られたものの，大きな差は見られなかった。

\section{考察}

本研究の結果から，スケトウダラ冷凍すり身から一定 の品質を有する生分解性フィルムを調製することが可能 であることが明らかとなった。よって, 冷凍すり身がこ れまで使用されていた水産練り製品の原料としてだけで なく, 生分解性フィルムの原料として用いることができ ることが明らかになった。

各種有機酸塩類の添加によりタンパク質溶解度が増加 したことから，これらがタンパク質可溶化剂として利用 可能であることが明らかとなり，この結果は桑原ら，14) 抢よびLeerahawong ら5)のスルメイカ筋肉を対象とし た，これに含まれるタンパク質に対する有機酸塩類の及 ぼす影響に関する研究結果と同様であった。塩の種類に よるタンパク質溶解度の違いは, 各種塩類のイオン強度 の違いによるものであると考えられた。すなわち，筋原 繊維を構成するミオシンフィラメントはイオン強度の増 加によって溶解することが知られているが, ${ }^{13)}$ 各種塩類 を $0.5 \%$ 添加した際のタンパク質溶解度はクエン酸 $\mathrm{Na}$ が最も大きい值 (12.7\%) を示した。同濃度でのイオン
強度は, クエン酸 $\mathrm{Na}$, 酢酸 $\mathrm{Na}$, 安息香酸 $\mathrm{Na}$, 酒石酸 $\mathrm{Na}$ ，および $\mathrm{NaCl}$ で，それぞれ $0.13,0.06,0.03,0.08$ お よび 0.09 であり, クエン酸 $\mathrm{Na}$ が最も大きなイオン強 度を有しているためであると考えられた。また, 対照に 扔いて, タンパク質溶解度は高かったが $(7.3 \%)$ ，この 原因として，サンプルとして用いた冷凍すり身中に若干 の水溶性タンパク質が含まれて扔り，これが影響した可 能性が示唆された。また, フィルムの厚さを測定した結 果, 安息香酸 $\mathrm{Na}$ を $1.0 \%$ 添加したフィルムに抢いて高 い值 $(42.9 \mu \mathrm{m})$ を示し, $\mathrm{NaCl}$ を $1.0 \%$ 添加したフィル ムに抢いて低い值 $(32.9 \mu \mathrm{m})$ を示した。本研究では乾 燥条件を一定にし, 水分活性が一定となるように乾燥を 行ったため, 結果としてフィルムの水分含量に差が生 じ，これがフィルムの厚さに影響を与えている可能性が 示唆された。Fig. 2 に示すように, 各種塩類の添加量の 増加に伴い TS は減少した。これは，各種塩類を $1.0 \%$ 添加することにより，0.5\% 添加した場合と比較して乾 燥後のフィルム中のタンパク質間に異物としての塩類が 入り込み，フィルム中のタンパク質相互のネットワーク が疎になったためと考えられた。クエン酸 $\mathrm{Na}$ を添加し たフィルムの TS が高い值を示したが，これはクエン酸 $\mathrm{Na}$ が他の有機酸塩に比較して高いタンパク質溶解性 （12.7\%）を示したことが要因であると考えられる。す なわち, 溶解したタンパク質同士の絡み合いが増加し, タンパク質分子間で疎水結合が多く形成されたためと考 えられた。15) また, クエン酸 $\mathrm{Na}$ 抢よび酒石酸 $\mathrm{Na}$ の添 加により調製したフィルムの TS は, 酢酸 Na 添加によ り調製したフィルムと比較して高かったが，この結果は コイのアクトミオシン溶液をゲル化させる際に, 酢酸 $\mathrm{Na}$ を添加したものと比較してクエン酸 Na 打よび酒石 酸 $\mathrm{Na}$ を添加すると強固なゲルが得られたという報告16) 
と同様の傾向であった。

$\mathrm{EAB}$ は, $\mathrm{NaCl}$ または各種有機酸塩類の添加により対 照と比較して高い值を示したが，このことからこれら各 種塩類がタンパク質可溶化剂としてだけでなく, 可塑剂 としても作用していることが示唆された。本実験で使用 した各種塩類およびグリセロールはいずれも低分子量で あるため, タンパク質間に容易に入り込むことができ る。そして, それらが有する親水基がタンパク質と水素 結合を形成することでタンパク質間の水素結合の形成を 妨げたため， EABが増大したもの17) と考えられた。ま た，本実験で使用した冷凍すり身には冷凍変性防止剂と してソルビトールおよびショ糖が合わせて $8 \%$ 前後含 まれているため, これらもフィルムの $\mathrm{EAB} に$ 影響して いるものと考えられる。Fig. 4 に見られるように, 安息 香酸 $\mathrm{Na}$ を $1.0 \%$ 添加して調製したフィルムの $\mathrm{EAB}$ は 特に高い值 $(201 \%)$ を示した。この理由に関しては各 種有機酸塩の分子量や親水基の数では説明することはで きず，本研究では明らかではなかった。一方で, 酒石酸 $\mathrm{Na} 1.0 \%$ 添加して調製したフィルムの EAB は低い 值を示し $(62 \%)$ ，そのフィルムは固く脆い性状を有し ていた。この $\mathrm{EAB} の$ 低下は, コンディショニングにお ける塩の結晶化に伴うフィルムの脆弱化が関与している ことも想定されるが， $\mathrm{NaCl}$ の添加によっても同様に塩 の析出が見られたものの, EAB は高い值を示したため $(190 \%)$, 塩の析出がフィルム性状に与える影響は明確 ではなかった。

$\mathrm{NaCl}$ あるいは各種有機酸塩類の添加および添加量の 増加に伴いWVP は増大した。これは, $\mathrm{NaCl}$ は高い吸 湿性を示し，5）また有機酸塩はこれが有するカルボキシ ル基およびヒドロキシル基などの親水基のため, WVP が上昇したものと推察された。17,18) クエン酸 Na および 酢酸 Na を添加したフィルムが高いWVPの值を示した が，これらが他の有機酸塩と比較して親水性が高いため かも知れない。

すり身フィルムは紫外部の光を透過しない性質を有し て抢り，これはすり身フィルム中の芳香族アミノ酸が有 する $280 \mathrm{~nm}$ 付近の紫外線を強く吸収する性質 ${ }^{4)}$ にる ものであると考えられた。また, 対照と比較して, 各種 有機酸塩を添加することにより吸光度は低い值を示し た。これは, Table 2 に示すように, $\mathrm{NaCl}$ および各種 有機酸塩の添加によりタンパク質溶解度は増加し（8.5$14.2 \%)$, これによりタンパク質分子が溶解し, 均一に なった結果, 吸光度が低くなったものと考えた。また,

$\mathrm{NaCl}$ を 1.0\% 添加して調製したフィルムでは最も吸光 度が高く, Fig. 1bに示すように視覚的にも確認できる 結晶化した塩の影響であると考えられた。一方, 酒石酸 $\mathrm{Na}$ を添加したフィルムにおいても同様に塩の析出が見 られたが，吸光度の值は低かった。 $\mathrm{NaCl}$ を添加したフ
ィルムと酒石酸 Na を添加したフィルムとでは塩の析出 の仕方が異なり， $\mathrm{NaCl}$ 添加のものは酒石酸 $\mathrm{Na}$ 添加の ものに比較して細かい塩の析出であったことが原因であ ると考えられた。

本研究結果から, 引っ張り強度が高かったこと, 吸光 度の值が低かったことから, クエン酸 Na を添加して調 製したフィルムの性状が最も優れていると思われた。

また, クエン酸 Naを $0.5 \%$ 添加して調製したフィル ムは, 翁ら ${ }^{4)}$ がフィルム形成懸濁液の $\mathrm{pH}$ を 3 に調整し たすり身フィルム（7.4 MPa， $160.9 \%$ および $0.73 \times$ $\left.10^{-10} \mathrm{~g} \cdot \mathrm{m}^{-1} \bullet \mathrm{s}^{-1} \bullet \mathrm{Pa}^{-1}\right)$ と比較すると, TS, EAB およ びWVPは劣っていた（5.1 MPa, 146.6\% および × 1.2 $\left.\times 10^{-10} \mathrm{~g} \cdot \mathrm{m}^{-1} \cdot \mathrm{s}^{-1} \cdot \mathrm{Pa}^{-1}\right)$ 。本研究でのフィルムの TS は, 翁らのものに比較して低い傾向を示したが, 翁らは $\mathrm{FFS}$ 調製段階でのタンパク質の溶解を, $\mathrm{pH}$ を低くする ことにより行っており, 本研究のイオン強度を用いたタ ンパク質の溶解法と異なるが，これら調製法の違いによ るものと考えられた。また， EABに関しては，本研究 ではグリセロール濃度がフィルム形成懸濁液に対して $0.6 \%(\mathrm{w} / \mathrm{w})$ であったのに対し, 翁らのフィルムでは 1.0\% (w/w) であることから, 可塑剤の絶対量の違い も一つの原因であると考えられた。WVPは添加した有 機酸塩の有する親水基の影響により, 有機酸塩を添加し ない翁ら ${ }^{4)}$ のフィムと比較して大きくなったものと考 えた。

以上のことから, 有機酸塩類の添加によりフィルム諸 性状の改善が可能であり, また, 用いる有機酸塩の種類 や添加量を変えることでフィルムの性質を用途に合わせ て変えることが可能であることが明らかになった。しか し, 各種性状に関して, 既存のフィルムと比較してまだ 劣っている点が多く, 今後更なる性状改善が必要である ことが示唆された。また, 本研究ではフィルムの基礎研 究であるため, 生産性については検討を行わなかった が，今後は連続的にフィルムを調製する方法についても 検討していく必要があると考えられる。

\section{文献}

1）二チモウ侏. 冷凍 $2010 ; 85: 23-25$.

2）黒川孝雄. 冷凍すり身の歴史. 冷凍 2010; 85: 571-576.

3) Krochta JM, Baldwin EA, Carriedo MN. Edible coatings and films to improve food quality. Technomic Publishing, Lancaster. 1994; 279-303.

4）翁武銀, Hamaguchi PY, 珠㺵裕介, 田中宗彦. 可食性 スケトウダラすり身フィルムの調製と性状. 食科工誌 2006; 53: 103-108.

5) Leerahawong A, Arii R, Tanaka M, Osako K. Edible film from squid (Todarodes pacificus) mantle muscle. Food Chemistry 2011; 124: 177-182.

6）菅原 潔, 福島正美. Kjeldahl 法.「蛋白質の定量法」 (瓜谷郁三, 志村憲助, 中村道徳, 船津 勝編), 東京大 学出版会, 東京. 1977; 23-73. 
7) Folch J, Less M, Stanley GHS. A simple method for the isolation and purification of total lipids from animal tissues. J. Biol. Chem. 1957; 226: 497-509.

8）竹下瑞恵, 大泉 徹, 赤羽義章, 竹縄誠之. コイ筋原纎 維の熱変性と溶解に及ぼすグルコン酸ナトリウムの影 響. 日水誌 1999; 65: 886-891.

9) Lowry OH, Rosebrough NJ, Farr AL, Randall RJ. Protein measurement with the forin phenol reagent. J. Biol. Chem. 1951; 193: 265-275.

10) ASTM. Annual book of ASTM standards. American society for testing and materials. Philadelphia PA. 1999.

11) Gontard N, Guilbert S, Cuq JL. Edible wheat gluten films: Influence of the main process variables on film properties using response surface methodology. J. Food Sci. 1992; 57: 190-195.

12) ASTM. Annual book of ASTM standards. American society for testing and materials. Philadelphia PA. 1987.

13) Laemmli UK. Cleavage of structural proteins during the assembly of the head of bacteriophage $\mathrm{T}_{4}$. Nature 1970; 227: 680-685.

14）桑原浩一, 大迫一史. スルメイカ外套膜筋の加熱ゲル形 成に及ぼすグルコン酸ナトリウムの影響. 日水誌 2003; 69: 637-642.

15）珠㺵裕介, Hamaguchi PY, 翁武銀, 田中宗彦. 魚類筋 原繊維タンパク質由来の生分解性フィルム形成メカニズ 么. 食科工誌 $2005 ; \mathbf{5 2}$ : 325-329.

16) Noguchi S, Matsumoto J. Modification of thermal and non-thermal gelation of carp actomyosin by additive compounds. Nippon Suisan Gakkaishi 1978; 44: 273-278.

17) Cuq B, Gontard N, Coq JL, Gilbert S. Selected functional properties of fish myofibrillar protein-based films as affected by hydrophilic plasticizers. J. Agric. Food Chem. 1997; 45: 622-626.

18) McHugh TH, Aujard JF, Krochta JM. Plasticized whey protein edible films: water vapor permeability properties. J. Food Sci. 1994; 59: 416-419. 